\title{
Further taxonomical and ecological studies on some marine gastropods of the intertidal zone between Safaga and EL Koseir at the Western coast of the Red-Sea-Egypt
}

Samir Beltagi and Omaima M.

Biological \& Geological Department, Faculty of Education, Ain Shams University

\begin{abstract}
Six different species relating to the class Gastropoda have been collected for the first time in the region between Safaga and EL Koseir along the sandy and rocky westernintertidal shallow shore of the western edge of the Red Sea. These 6 specimens are registered as $1^{\text {st }}$ record according to the Taxonomical and zoogeographical scientific studies and these are Conus virgo (Linnaeus 1758), Nerita albicilla (Linnaeus 1758), Nerita polita (Linnaeus 1758), Nerita undata (Linnaeus 1758), Cerithuim punctatum (Bruguiere 1792), and Planaxis sulcatus (Born, 1778).
\end{abstract}

Key words: Red Sea - Molluscs - Marine gastropods - Marine biology.

\section{INTRODUCTION}

Few research works have been done concerning the taxonomy and biology of gastropods especially in the Red sea. Further studies were published on the faunal composition of Molluscs, namely that of Cypracids (Foin, 197; Meinis, 1971; O'malley, 1971; Schilder, 1951). Additional knowledge about the distribution of Littoral molluscs in the Red sea, was given for strombids (Mienis, 1971), Conids (Khon, 1905), Terebids (Bratcher and Borch, 1967) and the work done by Mastaller (1978), and Sharabati (1981) and the taxonomy and the zoogeography of pelecypoda and gastropods of the Red Sea (Beltagi and Ghamrawy, 1985; Beltagi (2015).

\section{MATERIALS AND METHODS}

Six different species of gastropods were collected from the shallow upper intertidal zone in between Safaga and EL Koseir on the western inshore edge of the red sea Egypt (Fig. 1). Some specimens of gastropods are sampled by hand nets and others by using a dredge having an aperture of about 20x45 cm and a bag of one meter in length. Collection of samples was conducted in the period between 15-16 February 2016, under the supervision of the head of the biological and Geological Department of the Faculty of Education Ain Shams University. The Topography of the sampling area, is mostly sandy with some scattered pieces of rubbles and stones (Fig. 2). The salinity of the sea water ranges between 36-37\%.

\section{RESULTS AND DISCUSSION}

1- Conus virgo (Linnaeus 1758) (Fig. 3, A, B, C)

Systematic position

Phylum: Mollusca.

Class: Gastropoda

Subclass: Caenogastropoda

Order: Neogastropda

Super family: Conoidea

Family: Conidae

Genus: $\underline{\text { Conus }}$

Species: virgo (Linnaeus 1758) 
Samir M Beltagi and Omaima M.

Distribution: Entirely Indo-Pacific-Red Sea.

Habitat: in $0.5 \mathrm{~m}$ depth of the sandy shore and rubble on reef flats and beneath dead corals. Description:

Shell solid to heavy. Length ranges between 50-60 mm. Periostracum brown to faint yellowish coloration. Last whorl conical, Outline slightly convex at adaptical fourth, straight below. Shoulder angulate. Spire low, outline slightly concave to slightly convex. Teleoconch sutural ramps almost flat to slightly concave, late ramps with 3 increasing to 5-6 spiral grooves, either paralleled by additional striae or replaced by numerous in latest whorls. Last whorl with weak to obsolete, spiral ribs near base; widely spaced fine ribs and wrinkled threads between may extend to centre or beyond. Dorsum of foot white mottled with brown, with a cross-shaped block transverse blotch on anterior part, a black blotch at opercular area. Edge of foot yellow to orange. Radula teeth long and curved, with 2 opposite adapical barbs, serration extends more than halfway down the shaft terminating in a backward pointing cusp; base with a distinct spur (Bergh, 1895; Peile, 1939; Bandel, 1984).

2- Nerita albicilla (Linnaeus 1758) (Fig. 4, A, B)

\section{Systematic division}

Phylum: Mollusca.

Class: Gastropoda

Subclass: Neritimorpha

Order: Cyclonertimorpha

Super family: Neritoidea

Family: Neritidae

Genus: Nerita

Species: albicilla (Linnaeus, 1758)

Distribution: Red-sea, Indian and Pacific Ocean, East coast of South Africa.

Habitat: It is formed at shelters under rocky substratum between mid and low tides.

\section{Description:}

Shell with spire depressed width greater than height, sculptured with broad, low, spiral ribs. Columella deck pustulose, particularly at outer edge; columella concave centrally; smooth or with two or three weak teeth centrally. Outer lip with one or 2 strong posteriorly sometimes one anteriorly and 12-15 weak lirae. Exterior dull, black with white flecks or patches, often formed into two irregular spiral bands. Columella deck white, aperture white. Operculum calcareous, finely pustulose, grey or yellow. Shell size reaches about $16 \mathrm{~mm}$ in length.

3- Nerita polita (Linnaeus, 1758) (Fig. 5, A, B)

\section{Systematic position}

Phylum: Mollusca.

Class: Gastropoda

Subclass: Neritimorpha

Order: Cycloneritimorpha

Super order: Neritoidea

Family: Neritidae

Genus: Nerita

Species: polita (Linnaeus, 1758)

Description:

The shell with spire depressed, width greater than height. Exterior glossy, usually smooth about from fine axial growth lines, but occasionally with fine spiral ribbing. Columella deck smooth, columella straight, with 2-5 strong teeth at the center. Outer lip with about 20 weak 
Further taxonomical and ecological studies on some marine gastropods of the intertidal zone between Safaga and EL Koseir at the Western coast of the Red-Sea-Egypt

dentides. Exterior coloration variable; marbled streaked or banded with white, cream, grey or pink: Columella and inner band of outer lip usually deep orange or yellow columellar deck white. Operculum calcareous, pink, grey or black smooth and glossy with matt outer edge. Size: 15 to $30 \mathrm{~mm}$ high, 25 to $39 \mathrm{~mm}$ wide.

Distribution: Indo - Pacific region - Western Coast of the red sea- around northern Australia.

Habitat: on exposed rocky substratum.

4-Nerita undata (Linnaeus, 1758) (Fig. 6, A, B)

Systematic division

Phylum: Mollusca.

Class: Gastropoda.

Subclass: Prosobranchia.

Order: Cycloneritimorpha.

Family: Neritidae

Genus: Nerita

Species: undata (Linnaeus, 1758)

\section{Description:}

It has a globular shell, moderately developed high spire, colour variable, ranging from white to light brown with variable amounts of random black patches or stripes, sometimes with indistinct darker spiral bands, Operculum is calcareous. Sometimes all black, size $18 \mathrm{~mm}$ in length.

Locality: Collected from rocky parts of the in shore line and just below the high water level.

\section{5- Cerithuim punctatum (Bruguiere, 1792) (Fig. 7, A, B)}

\section{$\underline{\text { Systematic division }}$}

Phylum: Mollusca

Class: Gastropoda

Order: Caenogastropoda

Family: Cerithidae

Genus: Cerithuim

Species: punctatum (Bruguiere, 1792)

\section{Description:}

It has white coloration with black nodules. It has 10 to $12 \mathrm{~mm}$ height. Shells are elongate with many whorls, typically sculptured with spiral rows of nodules and axial ridges. There is usually an anterior and posterior canal and slightly expanded outer lip of the body whorl often with a varix; the operculum, oval and paucispiral.

Locality: It is collected from shallow intertidal zone which has a sandy Muddy substratum. Distribution: It is Indo-pacific- the western coast of the Red sea.

6- Planaxis sulcatus ( Born, 1778) (Fig. 8, A, B)

Systematic division

Phylum: Mollusca

Class: Gastropoda

Order: Caenogastropoda

Super family: Cerithidae

Family: Planaxidae

Genus: Planaxis

Species: $\underline{\text { Sulcatus }}$ (Born, 1778) 
Samir M Beltagi and Omaima M.

\section{Description:}

It is found in rocky intertidal environments throughout the indo-pacific region. The conical shell, speckled with patterns of white spots on a greenish-brown background. It height ranges between 20 to $35 \mathrm{~mm}$. Planaxis sulcatus has a shell with strong squarish spiral cords; shell has a blackish to cream sometimes with white or yellowish spots. Shell opening wide, inner surface white sometimes with dark purple grooves. Operculun thin; horn-like material and dark coloured; Body pale, small foot with a pale dark mottled pattern above, long tentacles with dark base. The tip of the shell is often eroded white. Inside the shell is white, with brown stripes following spirals.

The Biodiversity of the gastropodal species in the research work referred to the tolerance of these fauna to the effect of the physical and chemical factors subjected to them also the type of the bottom of the upper intertidal shallow sea-water. Some gastrods is adapted to live in muddy or sandy substratum; others are living upon rocky bottom. The larval stages the collected and identified species select the suitable habitats especially where suitable salinity and temperature and the Intensity of the light and dissolved gases $\left(\mathrm{O}_{2}\right)$ exist.

\section{Acknowledgments}

I would like to thank Prof.Dr.Mohamed Abd-ElAziz the head of the Biological and Geological department for his assistance to this research work, and also to Dr. Khaled Gomma, Mr. Magdy Maduen and Mr.Abd-EL-Moneim Laboratory specialist and the worker Mr.Arafa Ahmed Radwan.

\section{REFERENCES}

Abbott, R.T. (1960). The Genus Strombus in the Indo-Pacific, Indo-Pacific Mollusca, 1(2): 33-146.

Beltagi,. S. (2015). Further studies on Bivalves inhabiting the inter tidal zones of Port saied, Fayed and Hurghada, Egypt. Inter. J. Develop., 4(1): 115-123.

Beltagi, S. and Gamrawy, M.S. (1984). Studies on some pelecypods and Gastropods of shallow water in the region of North, Jeddah (Red sea) Prof. Symp. Coral reef environment Red sea, Jeddah 1984; 417-470.

Bratcher, T. and Burch, D. (1967). A New Terebrid species with checklist of Terebridae from the Red Sea (Mollusca, Gastropods). The Veliger, 10(1): 7-9.

Bruguiere, J.G. (1789-1816). Encyclopedia Methodique. Histoire Naturelle des Vers Paris, 6 vol.

Cernohorsky, O.W. (1967a). The Bursidae, Cymatiidae and Colubrariidae of Fuji Veliger, 9(3): 310-329.

Cernohorsky, O.W. (1967b). Marine Shells of the Pacific. Sydney: Pacific Publications, 248 pp.

Foin, T.C. (1972). The zoogeography of the Cypraeidae in the Red Sea basin-Argamon, Israel J. Malacol., 3(1-4): 5-16.

Forskal, P. (1775). Vermes I: Mollusca. Descriptiones animalium, avium, amphibiorum pescium, idectorum, vermium quae in itinere oriental observavit petrus Forskal., Copenhagen.

Hall, W.J. and Standen, R. (1907). On the Mollusca of a raised coral reef on the Red Sea Coast. J.. Conch., 12(3): 65-68.

Heba, T. (1964). Shells of the Western Pacific in color, II Hoikusha Pul. Co. Osaka: 1-233.

Issel, A. (1869). Malacologia del Mar Rosso. Pisa: 1-387.

Jickeli, C.F. (1874). Studien uber die Conchylien des des Rothen Meeres I. Die Gattung Mitra. Jahrb. Deutsch. Malakizool. Ges, I: 17-54. 
Further taxonomical and ecological studies on some marine gastropods of the intertidal zone between Safaga and EL Koseir at the Western coast of the Red-Sea-Egypt

Kay, E.A. (1979). Hawaiian Marine Shells. Reef and Fauna of Hawaii. Section 4: Mollusca. Bernice P. Bishop Museum Special Publication 64(4). Bishop Museum Press Honolulu, Hawaii.

Kira, T. (1962). Shells of the Western Pacific in color. Osaka Hoikusha.

Kohn, A.J. (1965). Conus (Mollusca, Gastropoda) collected by the Israel South Red Sea Expedition 1962, with notes from the Gulf of Aqaba Sinai Peninsula Sea fish. Res. Sta. Haifa Bull., 38: 54-59.

Lamy, E. (1916). Les Mactres et les lutraires de la Mer Rouge. Bul. Mus. Nat. Hist. Nat. Paris, 22: 237-309.

Lamy, E. (1917). Les Arches de la Mer Rouge. Bull. Mus. Nat. Paris. 23: 1-6.

Linnaeus, C. (1758). Systema naturae per regna naturae, (Editio decimal, reformata) Stockholm.

Mastaller M., (1978): The Marine Molluscan assemblages of port Sudan, Red Sea. Zoologische Mededelingen Uitgegevan Door Het. Ijksmuseum van natuurlijke Historie to Leiden (Ministerie van Cultuur, Recreatie en Maatschappelijk Werk) Deel 53 no. 13. Ruhr-Universitat Bochum, Lehrstuhl fur Spez. Zoologie Bechum, West Germany with one text-figure and one table.

Mienis, H.K. (1970). A checklist of Terebridae from the northern part of the Red Sea, with notes on Terebra arcolata. T. consobrina and T. subulata. J. Malacol. Soc., 1(2).

Mienis, H.K. (1971a). Strombidae (Mollusca, Gastropoda) collected by the Israel South Red Sea Expedition 1962. Argamon, 2.

Mienis, H.K. (1971b). Capracidae from the Sinai area of the Red Sea. Argamon, 2(1-2): 1344.

O'Malley, J. (1971). Identification Guide: Cowries of the Jeddah Red Sea Area of sea and shore publ., 1-16.

Rosewater, I. (1965). The family Tridacnidae in the Indo-Pacific. Indo-Pacific Molluscs., 1(6): 347-306.

Schilder, F. A. (1965). The Cypraeidae of the Israel South Red Sea expedition 1962. Sea Fish. Res. Sta. Haifa Bull., 40: 75-78.

Sharabati D. (1991). Saudi Arabian Sea-Shells selected Red Sea and Arabian Gulf Molluscs. Library of Congress Catalog Card Number 81-52534. Printed in the Netherlands by Royal Smeets offset B. V. Weest.

Shopland, F.R. (1902). List of marine shells collected in the neighbourhood of Aden between 1802 and 1901.Proc. Mal. Soc. London, 5(2): 171-179.

Sturany, R. (1901). Lamellibranchiaten des Roten Meeres. Ber. Comm. Ocean. Forschungen., 7: 255-205.

Sturany, R. (1903). Gastropoden des Roten Meeres. Denkschr. Math-naturwiss. Cl. K. Aked. Wiss. Wien, 74: 210-283. 
Samir M Beltagi and Omaima M.

مزيد من الدراسات التصنيفية و البيئية على بعض الرخويات البحرية في منطقة المد والجزر بين سفاجا والقصير على الاجى الساحل الغربي للبحر الاحمر - مصر في منرة

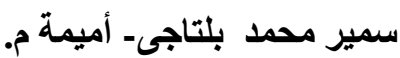

$$
\begin{aligned}
& \text { قسم العلوم البيولوجية و الجيولوجية ـ- ـ كلية التربية- جامعة عين شمس }
\end{aligned}
$$

تم جمع 6 أنو اع من البطنقدميات المختلفة وذلك لأول مرة على المبلى الساحل الغربى للثشاطئ الغربى لمياه البحر الأحمر

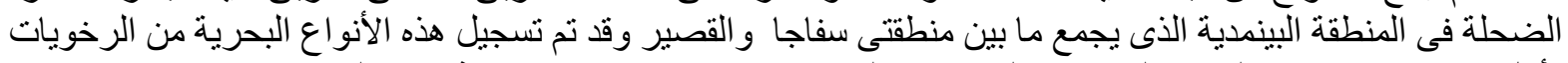

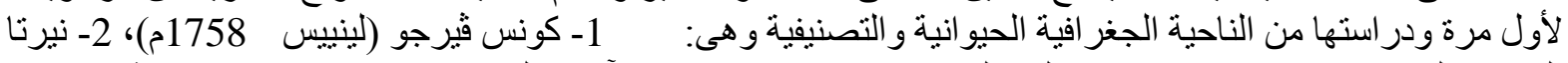

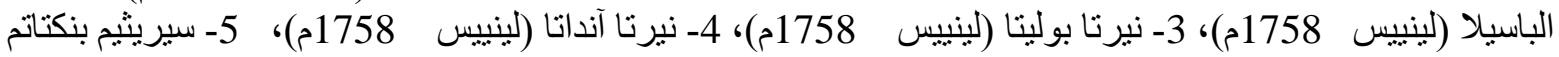

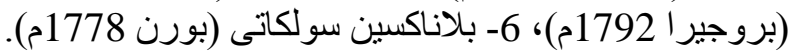


Further taxonomical and ecological studies on some marine gastropods of the intertidal zone between Safaga and EL Koseir at the Western coast of the Red-Sea-Egypt

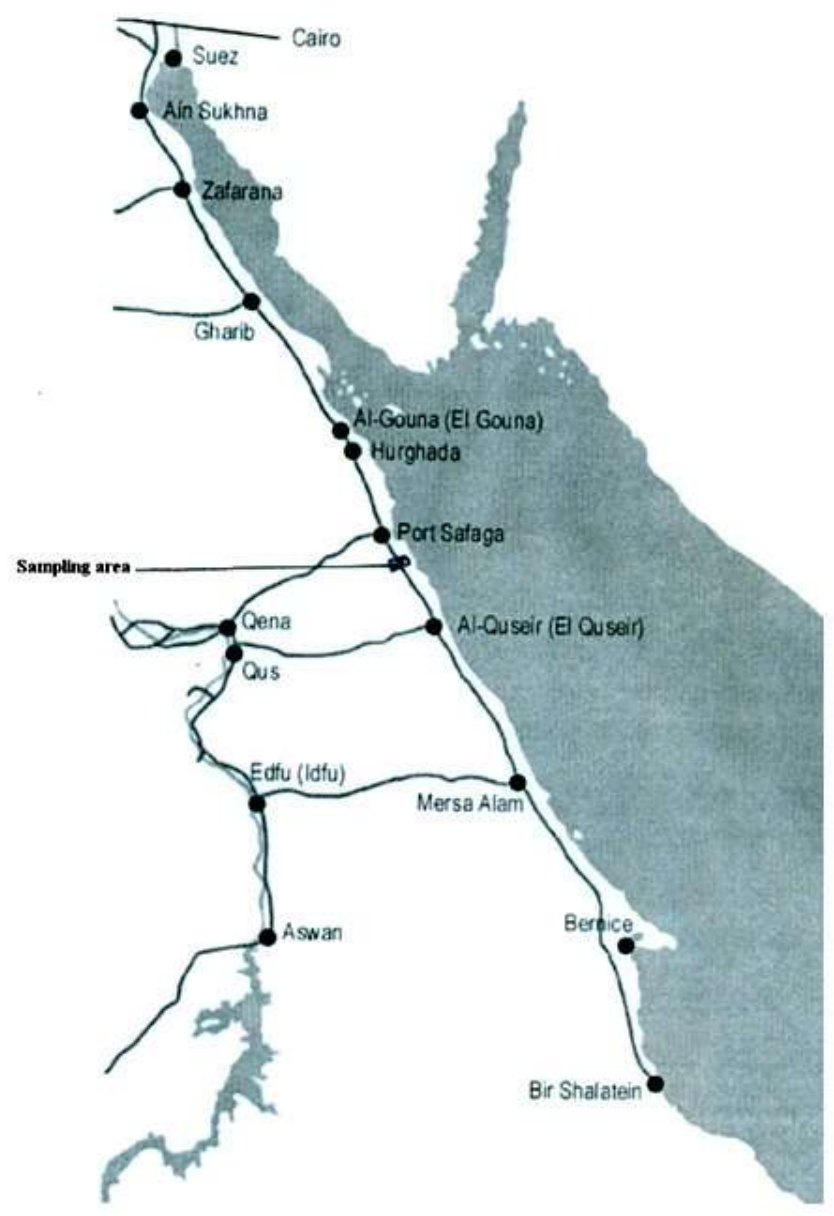

Fig. (1): Map of the western Red Sea coast (sampling area).

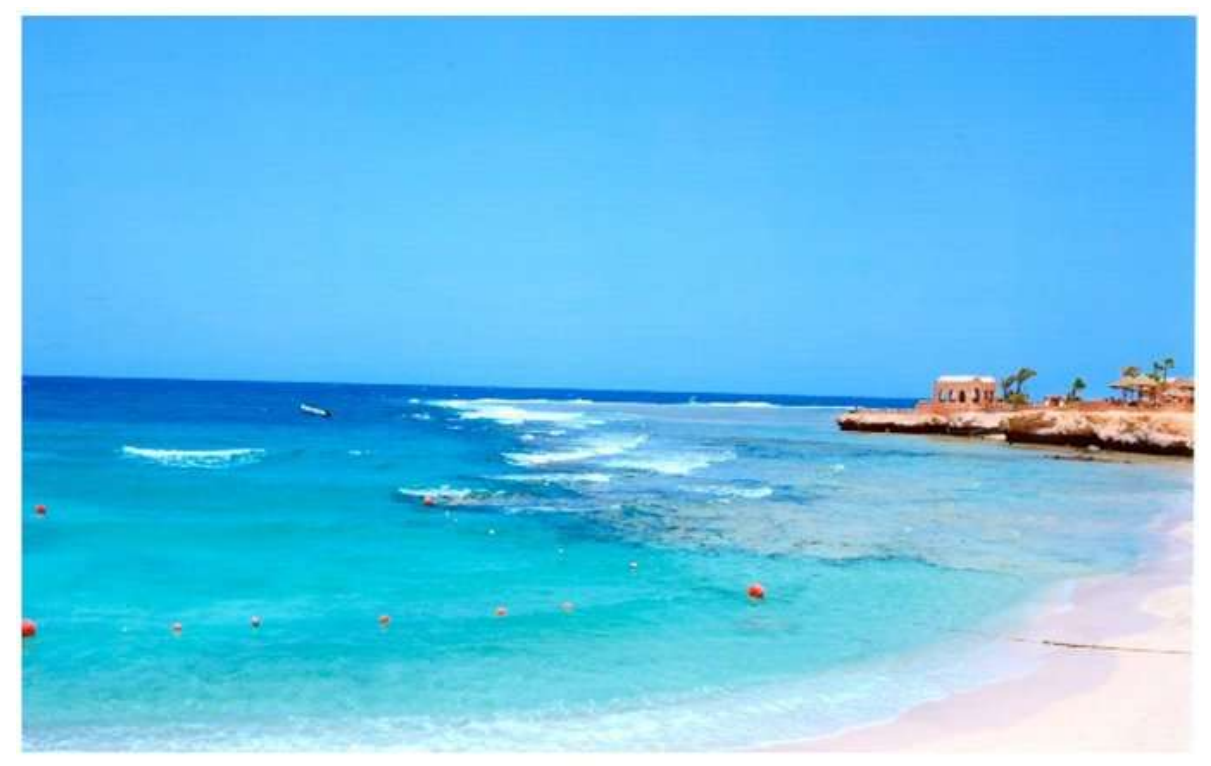

Fig. (2): Natural view showing the sampling area. 
Samir M Beltagi and Omaima M.

A

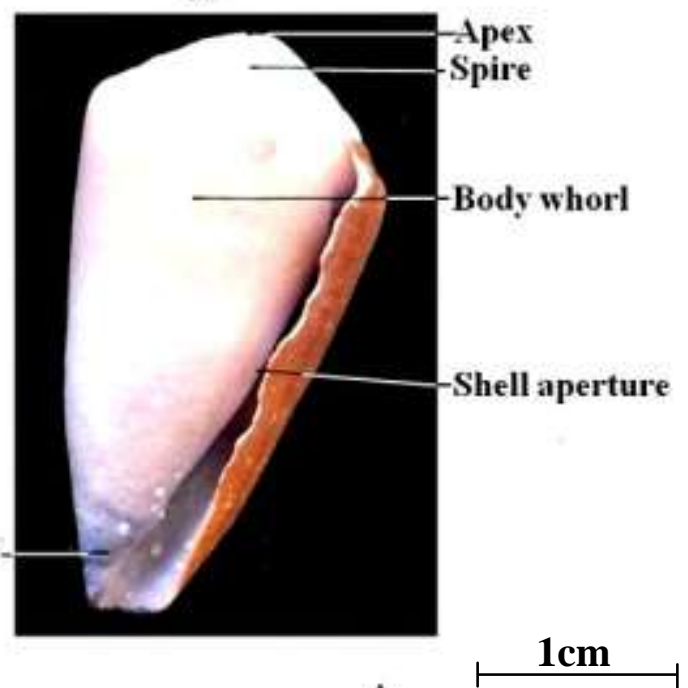

A

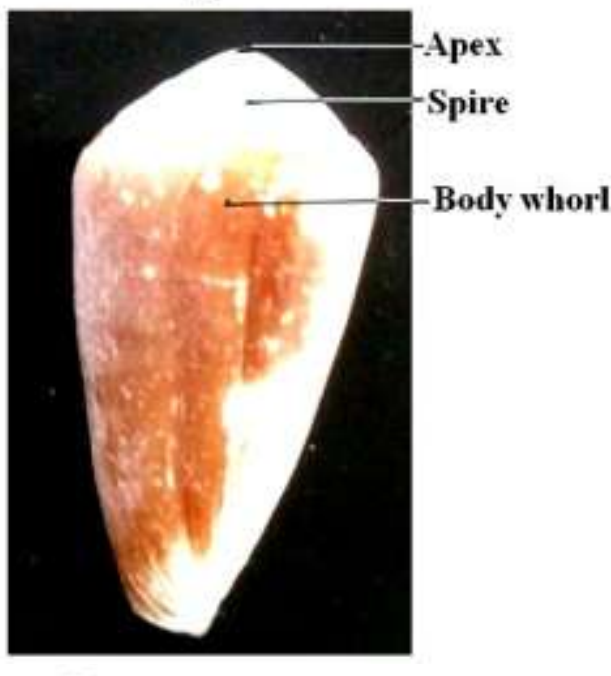

B
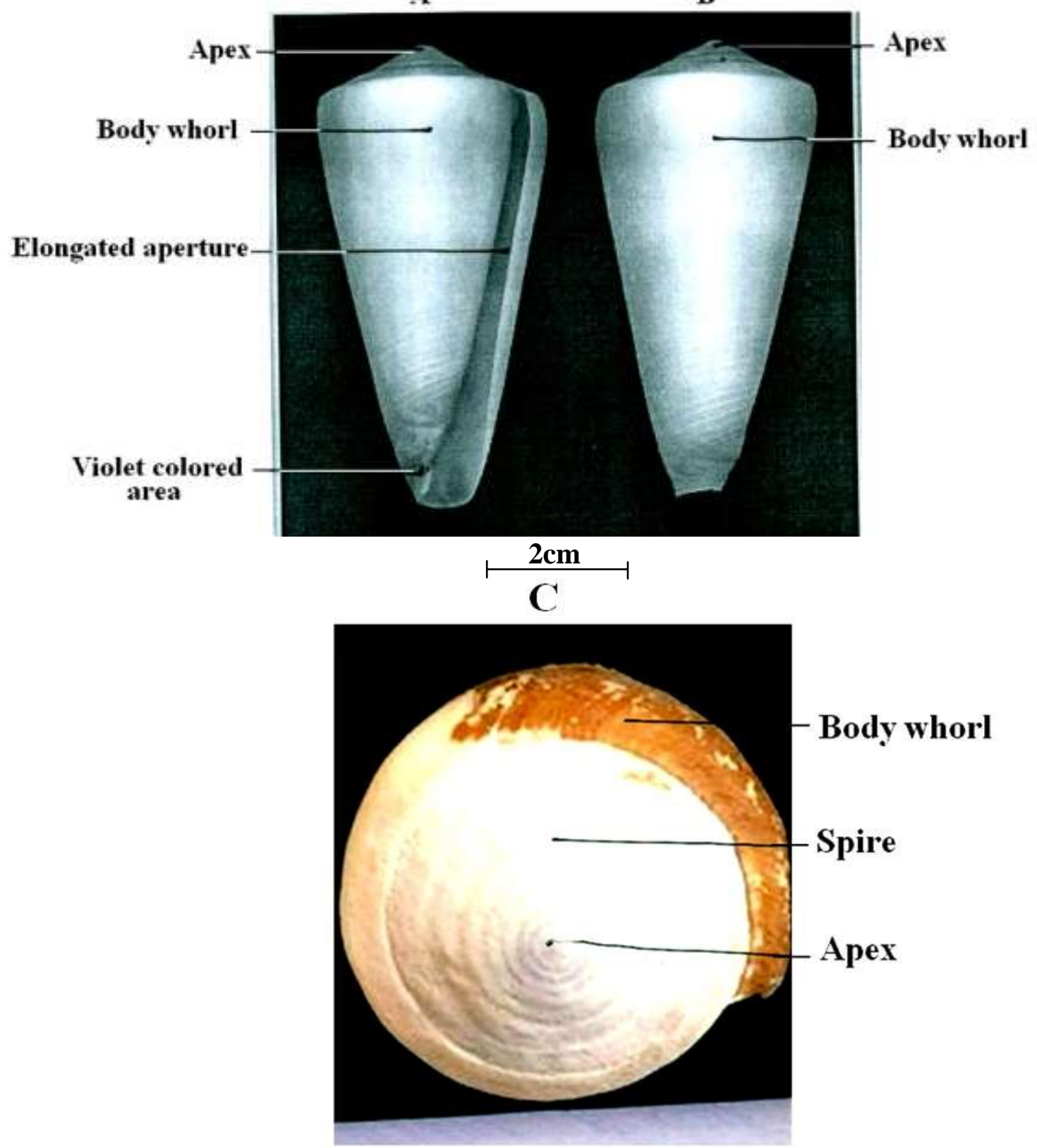

Fig. (3): Photomicrograph of Conus virgo (Linnaevs 1758) of the shell
(A)Ventral view
(B) Dorsal view
(C) upper view of the spirall 
Further taxonomical and ecological studies on some marine gastropods of the intertidal zone between Safaga and EL Koseir at the Western coast of the Red-Sea-Egypt

A

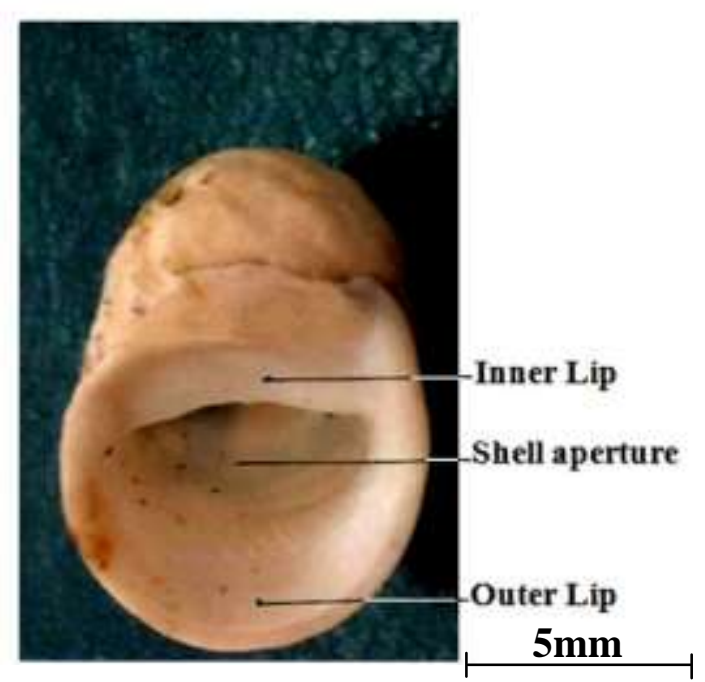

Fig. (4): Photomicrograph of Nerita albicilla (Linnaeus 1758)

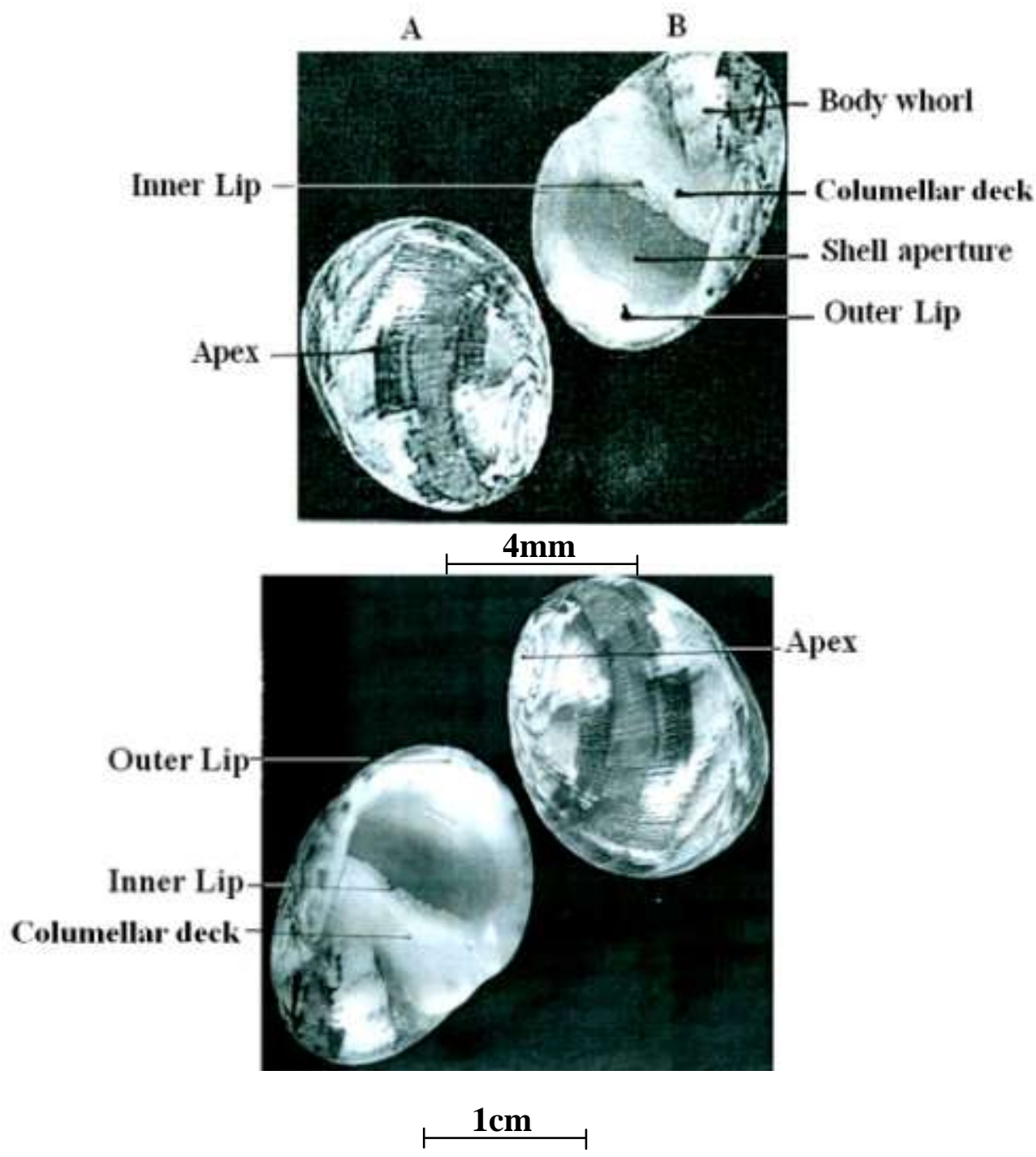

Fig. (5): Photomicrograph of Nerita polita (Linnaeus 1758)
(A)Ventral view
(B) Dorsal view

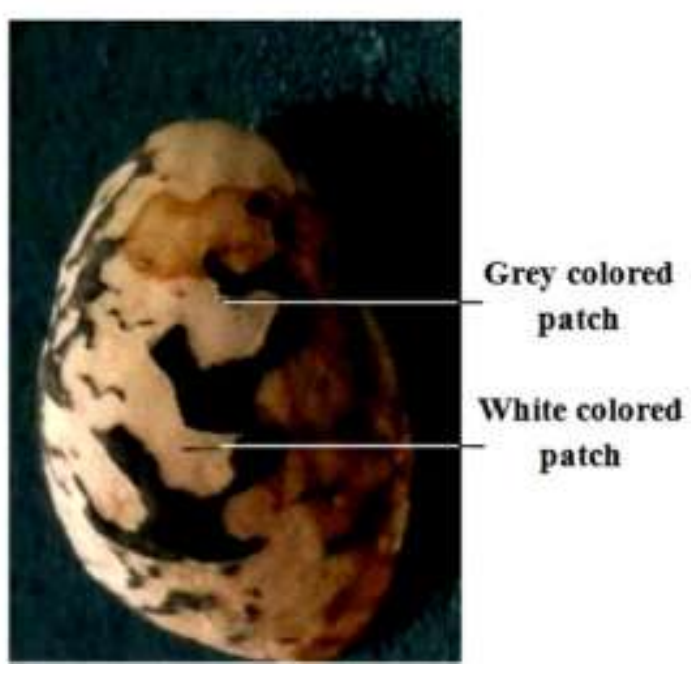

(B) Dorsal surface 
Samir M Beltagi and Omaima M.

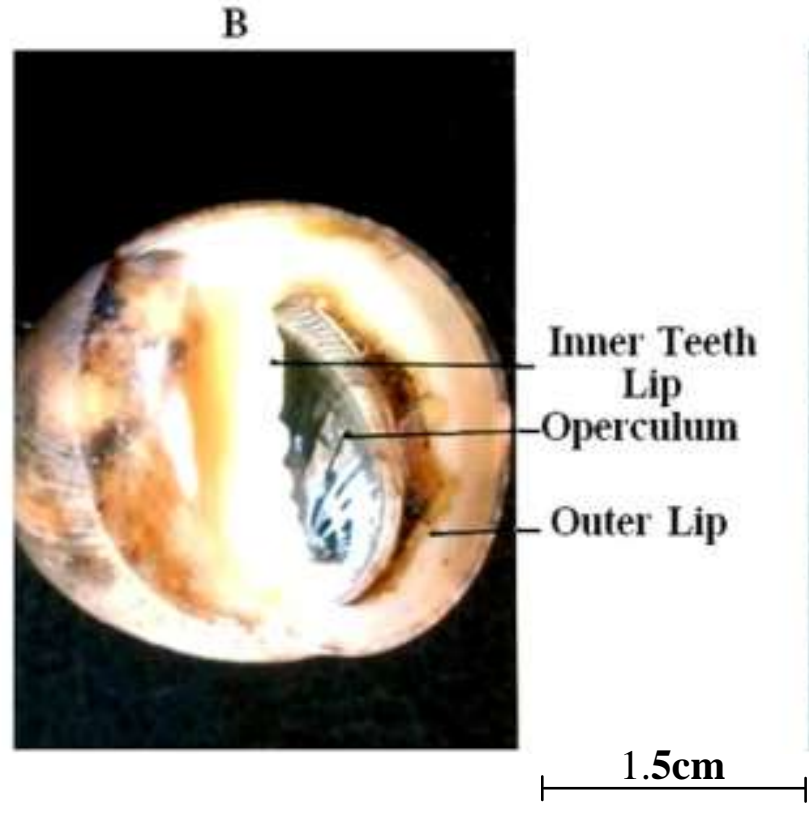

A

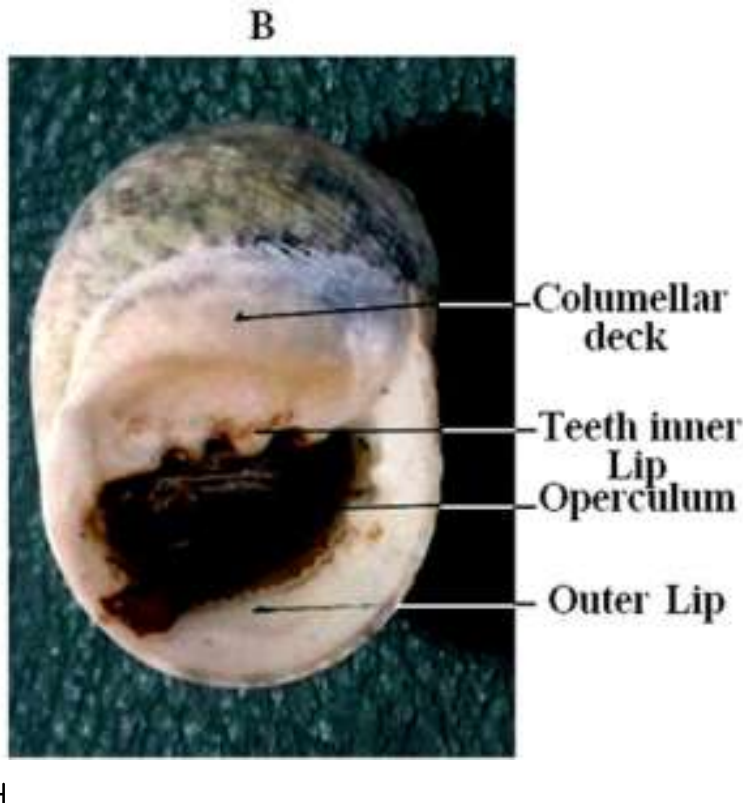

B

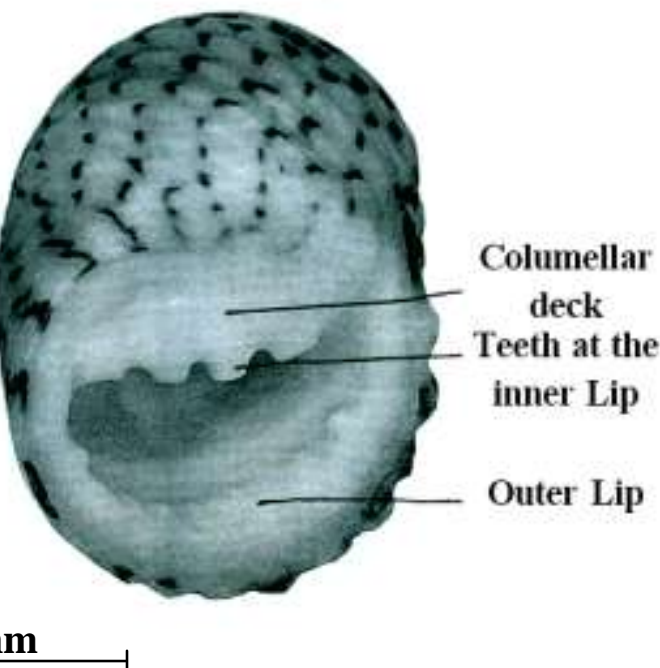

Fig. (6): Photomicrograph of Nerita undata (Linnaeus 1758)
(A) Dorsal view
(B) Ventral view 
Further taxonomical and ecological studies on some marine gastropods of the intertidal zone between Safaga and EL Koseir at the Western coast of the Red-Sea-Egypt

A $\quad$ B

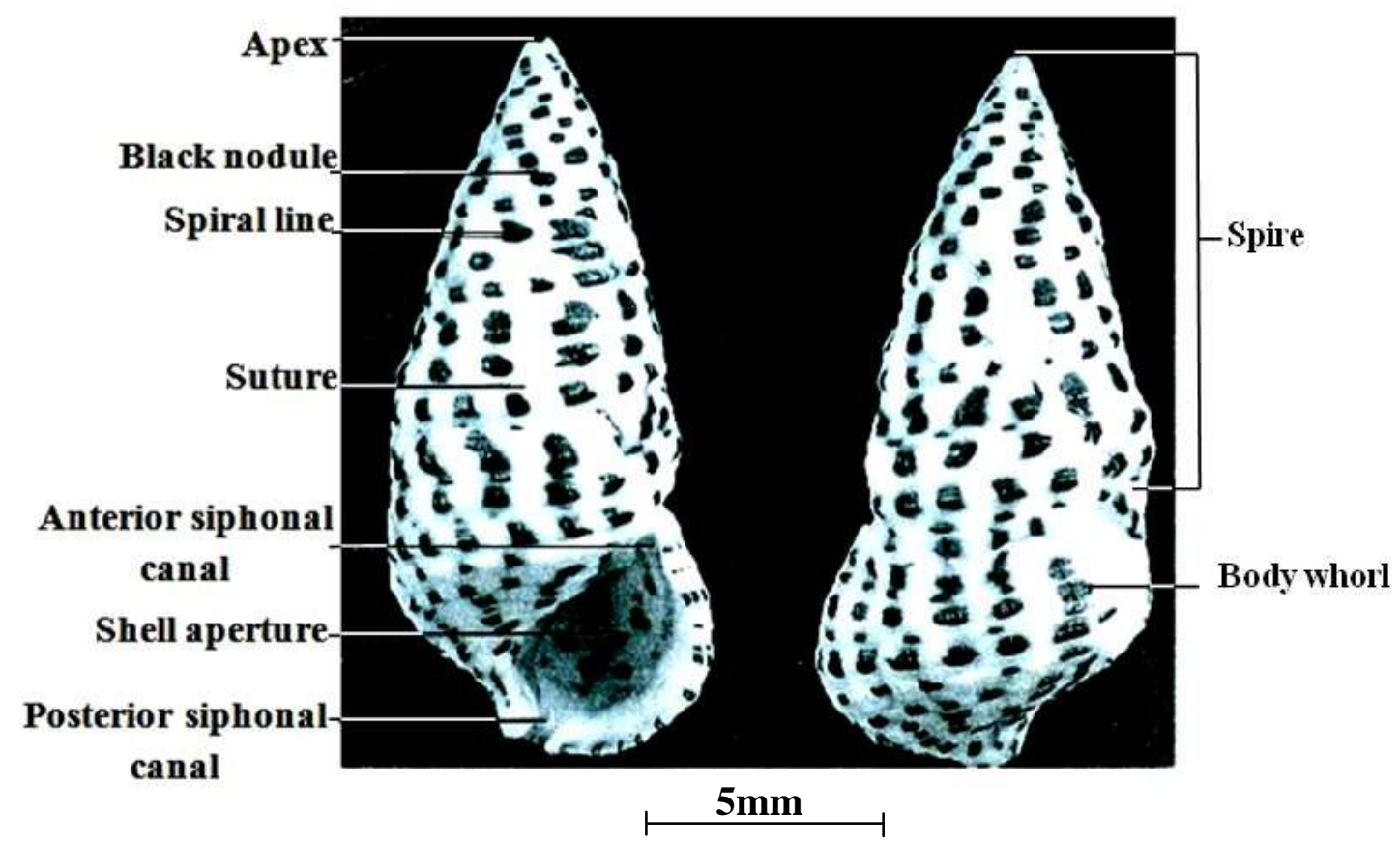

Fig. (7): Photomicrograph of Cerithium punctatum (Bruguires 1792)
(A) Ventral view
(B) Dorsal view

A

B

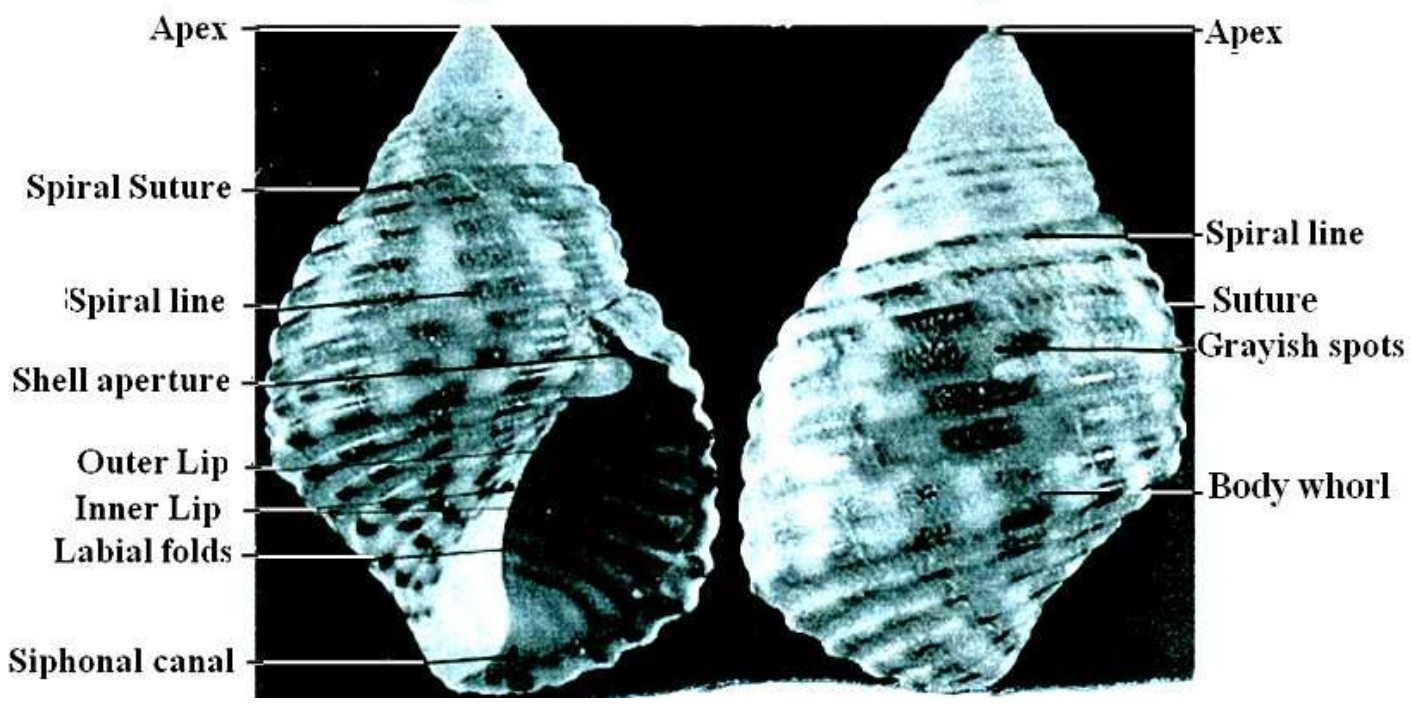

$5 \mathrm{~mm}$

Fig. (8): Photomicrograph of Planaxis sulcatus (Born 1778)
(A) Ventral view
(B) Dorsal view 